\title{
Herring Investigations at Plymouth. IV. The Growth of Young Herrings in the Neighbourhood of Plymouth.
}

\author{
By \\ E. Ford, A.R.C.Sc. \\ Naturalist at the Plymouth Laboratory.
}

With 1 Chart and 4 Figures in the Text.

Comparatively little has been published concerning the habitat and growth of young herrings in the English Channel, especially during the first year of their life. On May 26th, 1927, the first of a series of hauls with a small-meshed Saltash tuck seine (vide Davis, 1, p. 70, for a description of this type of net) was made in the River Tamar and a fine haul of young clupeoids obtained, which included the young of the herring, sprat and pilchard. Since then, regular samples have been taken from the rivers Tamar, Tavy and Lynher, and sufficient numbers of young herrings collected on each occasion to give a reasonable indication of the length-distribution prevailing. Sampling is still in progress and will be continued until one year's observation has been completed, but sufficient data are now to hand to merit an initial report. The localities from which the samples were obtained are indicated in the accompanying chart.

Before proceeding to a discussion of the data obtained, one or two facts need to be commented upon. In the first place it may be accepted as definitely established that the mesh of the seine used was of such a size that no question of serious selectivity among the " $\mathrm{O}$ " group populations during the period of sampling can arise. The net was proved to be capable of capturing young sprats in quantity which were much smaller than the great bulk of the smallest herrings taken on May 26th, 1927, while it could also capture older herrings much larger than the largest of the " $O$ " group. Probably, however, in the coming months of, say, March and April and even early in May, 1928, the selective action of the net will need to be taken into account. The second fact, apart from its explanation, is of immediate interest because of its effect on the choice of a standard measurement of length. A regular experience throughout the sampling has been to find that a large proportion 
of the young herrings had an incomplete caudal fin. The condition of the tail in such specimens presented an appearance which suggested that it had been "nibbled." Slightly affected cases had only a small portion of one fluke missing, but in the more severe cases the caudal peduncle alone remained. This tail affection obviously made it impossible

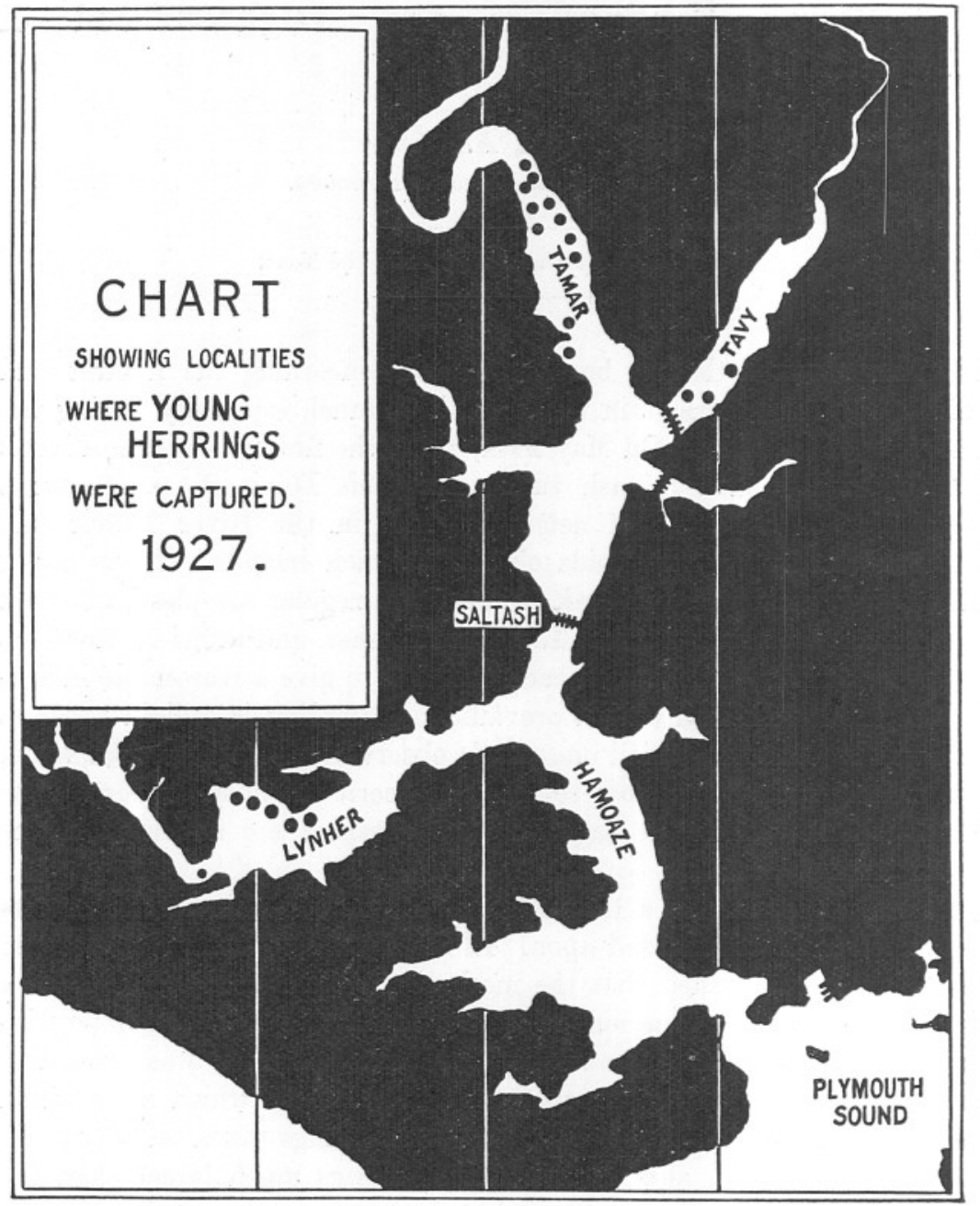

to determine the total length from the tip of the snout to the end of the dorsal fluke of the tail. To have discarded all affected specimens would have meant the sacrifice of the major portion of every haul, and rather than do this it was thought better to adopt some other standard of length. It was therefore decided to use the body length from the tip 
of the snout to the end of the caudal peduncle, instead of the total length to the end of the caudal fin. This standard of length, although perfectly satisfactory in practice, has the disadvantage that it is not in common use, so that the data on growth are expressed in terms unfamiliar to other workers. To meet this objection so far as is possible, both the body length and the total length have been determined for each of a large number of normal-tailed specimens covering the whole range in size, and a correlation table drawn up from which it is possible to read off the total lengths corresponding with given body lengths (see p. 309).

As a rule hauls of the seine were kept separate, and a sufficient number of hauls taken on each occasion to give as good a representation as possible of the stock present. It was found that hauls taken at the same place during the same visit differed to some extent in their size composition, due, one believes, to the tendency on the part of the fish to segregate into shoals according to size. By increasing the number of hauls and adding together the data for the day, the effects of this segregation were probably fairly well overcome. The actual measurements of length were made to the "nearest $5 \mathrm{~mm}$. below," and the data grouped into $5 \mathrm{~mm}$. classes. For example, all fishes from $65 \mathrm{~mm}$. to $69 \mathrm{~mm}$. were included in the $65 \mathrm{~mm}$. class. Particulars and data for each sample are given in the tables at the end of this paper.

It became evident at an early stage that there was an appreciable difference in size distribution between the normal-tailed and the abnormal-tailed specimens of the same sample, the proportion of the smaller sizes being greater among the latter. There was also an indication that among the abnormal-tailed specimens themselves, size distribution was dependent upon the degree to which the tail was affected. This may be illustrated by an analysis of a sample taken on October 20th, 1927 , in which the abnormal-tailed specimens were grouped into two classes, according to a rough standard of severity in tail affection as shown in the photographs in Fig. 1 :-

\begin{tabular}{|c|c|c|c|c|c|c|c|c|c|c|c|c|c|c|c|}
\hline & & 80 & 85 & 90 & 95 & 100 & ngth. & $\begin{array}{l}12 \mathrm{le} \\
\mathrm{mm} . \\
110\end{array}$ & $\begin{array}{l}\text { ngth } \\
115\end{array}$ & 120 & 125 & 130 & 135 & Totals & $\begin{array}{c}\text { Median } \\
Q_{2} . \\
\text { mm. }\end{array}$ \\
\hline & $1-3$ & 5 & 14 & 25 & 30 & 21 & 23 & 14 & 11 & 5 & - & 1 & - & 149 & $100 \cdot 2$ \\
\hline & $4-7$ & - & - & 3 & 14 & 33 & 34 & 25 & 18 & 14 & 7 & 4 & 1 & 153 & $109 \cdot 0$ \\
\hline
\end{tabular}

The Saltash fishermen assert that a big flow of fresh water down the rivers, as the result of heavy rains, drives fish downstream into the lower reaches of the estuary. Now if, as seems possible, the bigger fishes are more susceptible to a marked freshening of the water than are the smaller ones, then samples taken during the periods of such freshening would 
show a resultant lower average size. When the fresh water "dried up," as the fishermen would say, the bigger fish would return to their usual haunts upstream, with the result that the sample average would rise again. Such a phenomenon would tend to cause some irregularity in the general upward trend of the average size as calculated from sample data.

As the immediate purpose of this paper is to describe the broad features of the growth of the general stock of young herrings in

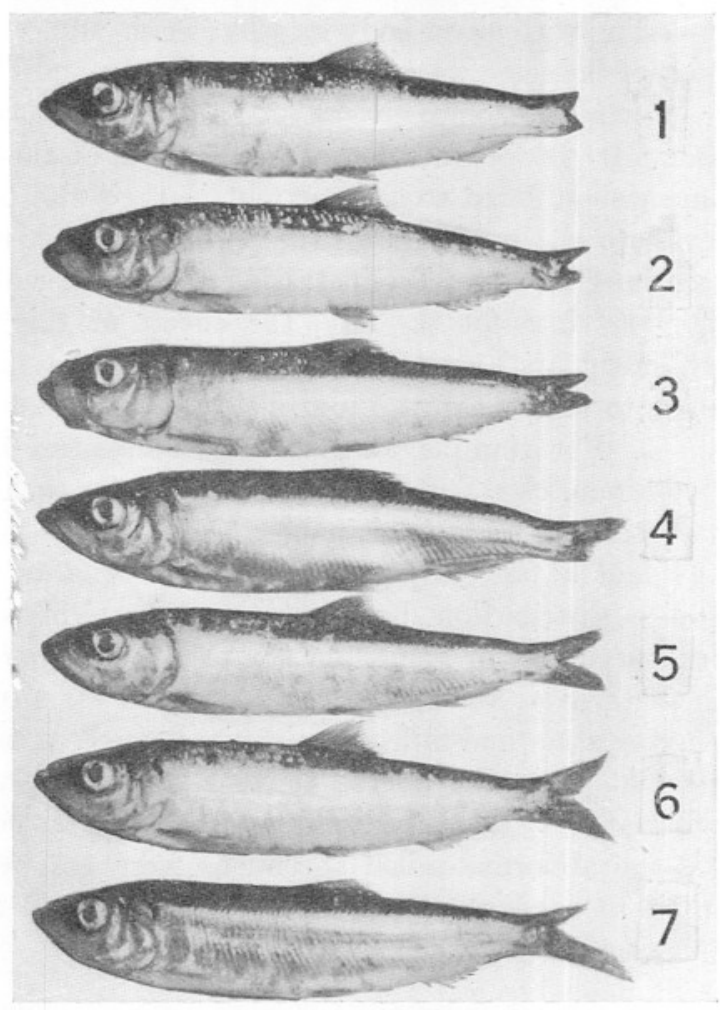

Fig. 1.-Seven examples of young herrings from Tamar with abnormal tails. Body length $95 \mathrm{~mm}$. 1927. (ca. $\left.\times \frac{4}{7}\right)$.

the area, the summarised data, as shown in Tables V and VI (p. 319), may be used. It will be realised, however, from what has been said above, that the estimates of growth derived from these summaries are subject to correction for the reasons stated. It is at once seen that throughout the period of sampling there was always a considerable range in size among the individuals of any one sample. The difference in size between the fishes of the first sample (May 26th, 1927) is believed to be due, in the main, to a difference in the time at which the fishes were 
spawned. Between 200 and 300 of the specimens in this sample had not yet completed their metamorphosis; these may be regarded as the final contribution from the winter spawning season of 1926-27, which, as was shown in Part III (see p. 284), may have commenced as early as October, 1926, and finished as late as March, 1927. The question of the difference in size directly attributable to a difference in time of birth can only be approached with confidence, however, when samples taken during the early months of the year 1928 become available. The extent of the range in size within the sample showed no tendency to diminish as time went on ; if anything, the later samples showed an even greater range. It is quite feasible that abnormality of the tail reduces the general efficiency for hunting food, with the result that badly affected specimens are less fortunate than their healthier associates and, in consequence, grow less. Certainly, as has already been shown, abnormal-tailed specimens were on average smaller than normal-tailed ones, and the more severe the affection, the less the average size.

\section{Proportionate Length of the TaIL.}

The body length and the total length were determined for each of 1305 . specimens with unaffected tails, and the data are shown in the form of a correlation table (Table II, on p. 316). There is an almost perfect correlation between the two measurements, and it may be taken that for any value $\left(\mathrm{L}_{\mathrm{B}}\right)$ of the body length, the corresponding total length $\left(\mathrm{L}_{\mathrm{T}}\right)$ is approximately $7 / 6 \mathrm{~L}_{\mathrm{B}}$. It is interesting to observe that this proportion holds good to a strikingly close degree for a total of 1075 adult herrings measured at Plymouth by Orton (2). The latter data are given in Table I, p. 315, but the following summary may be used to demonstrate the observation:-

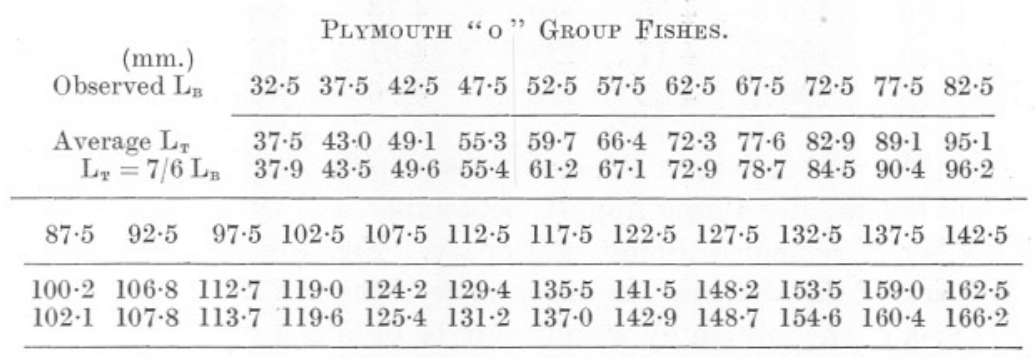

\begin{tabular}{|c|c|c|c|c|c|c|c|c|c|}
\hline$\underset{\mathrm{L}_{\mathrm{B}}}{\text { (em.) }}$ & $18 \cdot 5$ & $19 \cdot 5$ & RTON' & ADUI & Fist & $23 \cdot 5$ & $24 \cdot 5$ & $25 \cdot 5$ & $26 \cdot 5$ \\
\hline $\mathrm{L}_{\mathrm{T}} *$ & $21 \cdot 9$ & $23 \cdot 0$ & $24 \cdot 1$ & $25 \cdot 2$ & $26 \cdot 3$ & $27 \cdot 5$ & $28 \cdot 5$ & $29 \cdot 75$ & 31.5 \\
\hline $\mathrm{L}_{\mathrm{r}}=7 / 6 \mathrm{~L}_{\mathrm{B}}$ & $21 \cdot 6$ & $22 \cdot 75$ & $23 \cdot 9$ & $25 \cdot 1$ & $26 \cdot 2$ & $27 \cdot 4$ & $28 \cdot 6$ & $29 \cdot 74$ & $30 \cdot 9$ \\
\hline
\end{tabular}




\section{Tamar Samples}

The data for the Tamar samples are given in Tables III and V on pp. 317 and 319, and shown graphically in Fig. 2. If the curve $\mathrm{AB}$ be accepted as a reasonable approximation to the general upward trend of

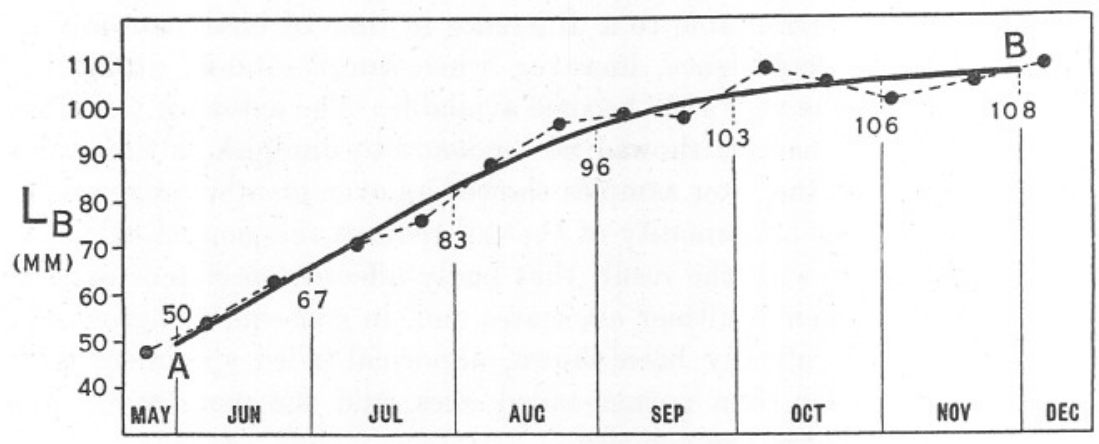

FIG. 2.-Median body length $\left(\mathrm{L}_{\mathrm{B}}\right)$ for samples of young herrings caught in Tamar, 1927. The curve A B is a freehand curve indicating the general upward trend of the median. The values of the median on the first day of each month is shown.

the median body length $\left(\mathrm{L}_{\mathrm{B}}\right)$, then it is seen that the average growth from month to month may be expressed as follows :-

\begin{tabular}{|c|c|c|c|c|c|c|}
\hline \multirow{2}{*}{$\begin{array}{l}\text { Date. } \\
1927 . \\
\text { June 1st }\end{array}$} & \multicolumn{2}{|c|}{$\begin{array}{c}\text { Median Body Length. } \\
\mathrm{L}_{\mathrm{B}} \text {. }\end{array}$} & \multicolumn{2}{|c|}{$\begin{array}{l}\text { Median Total Length. } \\
\qquad \mathrm{L}_{\mathrm{T}}=7 / 6 \mathrm{~L}_{\mathrm{B}} .\end{array}$} & \multicolumn{2}{|c|}{$\begin{array}{l}\text { Median Total Length. } \\
\text { Monthly increments. }\end{array}$} \\
\hline & $\begin{array}{c}\mathrm{mm} . \\
50\end{array}$ & $\begin{array}{c}\text { inches. } \\
2 \cdot 0\end{array}$ & $\begin{array}{c}\mathrm{mm} . \\
58 \cdot 3\end{array}$ & $\begin{array}{c}\text { inches. } \\
2 \cdot 3\end{array}$ & $\mathrm{~mm}$ & inches. \\
\hline July 1st & 67 & $2 \cdot 6$ & $78 \cdot 1$ & $3 \cdot 1$ & June, $19 \cdot 8$ & $0 \cdot 78$ \\
\hline Aug. 1st & 83 & $3 \cdot 3$ & $96 \cdot 8$ & $3 \cdot 8$ & July, $18 \cdot 7$ & $0 \cdot 74$ \\
\hline Sept. 1st & 96 & $3 \cdot 8$ & $112 \cdot 0$ & $4 \cdot 41$ & Aug., $15 \cdot 2$ & $0 \cdot 60$ \\
\hline Oct. 1st & 103 & $4 \cdot 06$ & $120 \cdot 1$ & $4 \cdot 73$ & Sept., $8 \cdot 1$ & $0 \cdot 32$ \\
\hline Nov. 1st & 106 & $4 \cdot 17$ & $123 \cdot 6$ & $4 \cdot 87$ & Oct., 3.5 & $0 \cdot 14$ \\
\hline Dec. 1st & 108 & $4 \cdot 25$ & $126 \cdot 0$ & $4 \cdot 96$ & Nov., $2 \cdot 4$ & 0.09 \\
\hline
\end{tabular}

Thus, the median length increased most rapidly during June and July, less and less rapidly during August, September, and October, until during November it remained almost stationary. Fig. 3 will convey a good impression of the alteration in appearance of the fish as growth proceeds. Some idea of the growth by weight may be obtained by using the values of the cubes of the successive total lengths as functions of the weights as shown on page 312 .

It is seen that whereas in the case of length, the monthly increment added falls continuously from June onwards, the increment of weight increases from June to the maximum in August, and then subsequently falls away, arriving at the minimum in November. 


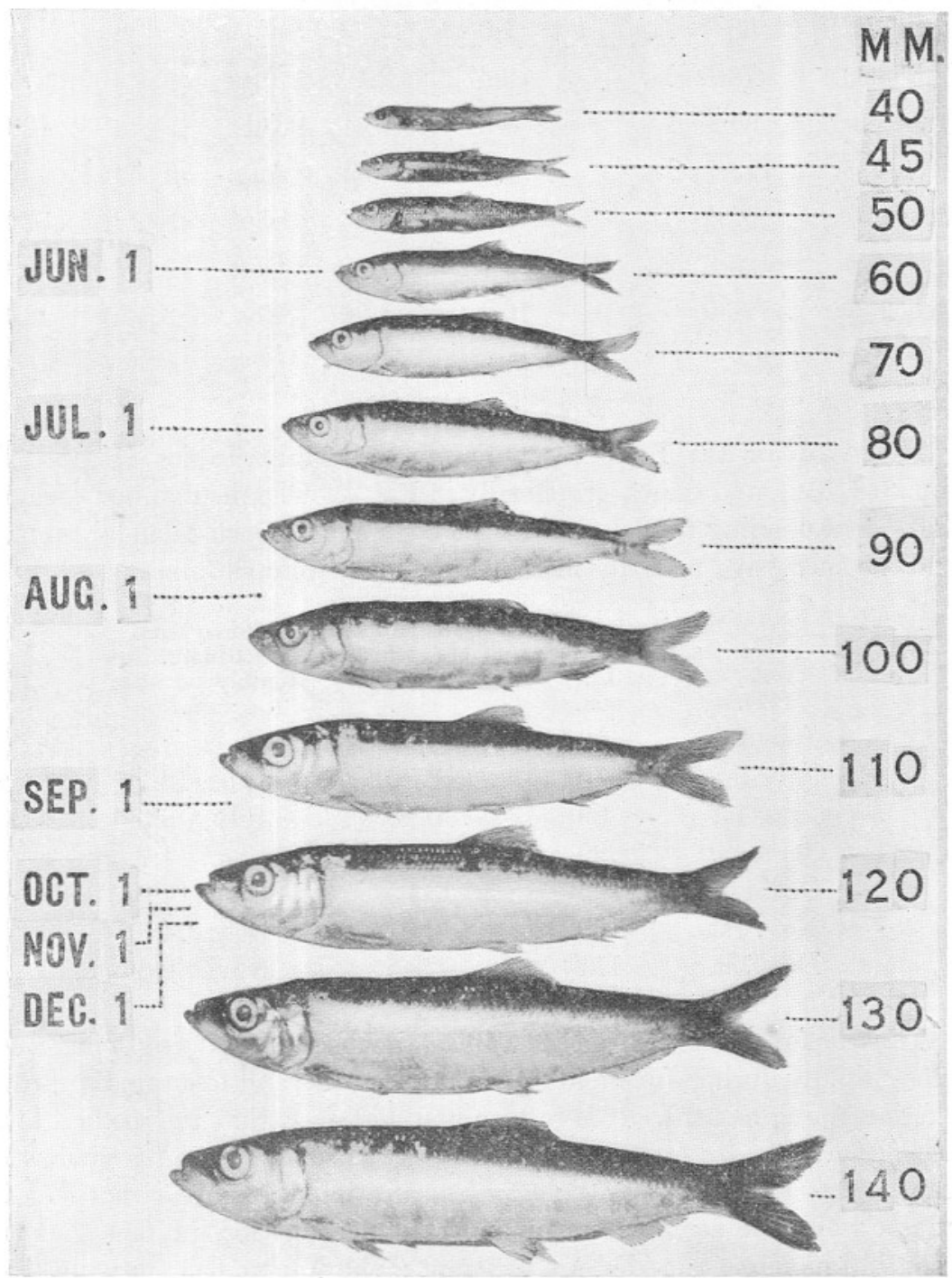

FIG. 3.-Photograph to illustrate the average growth made by the Tamar fish from June 1st to December 1st, 1927. The total lengths $\mathrm{L}_{\mathrm{T}}$ are shown. $\left(c a . \times \frac{1}{2}\right)$. 


\begin{tabular}{|c|c|c|c|c|}
\hline $\begin{array}{l}\text { Date. } \\
1927 .\end{array}$ & $\begin{array}{c}\text { Median } \\
\text { Total Length. } \\
\mathrm{L}_{\mathrm{T}} \\
\mathrm{mm} .\end{array}$ & $\left(\begin{array}{l}\mathrm{L}_{\mathrm{r}_{x}} \\
\tilde{\mathrm{L}}_{\mathrm{r}_{1}}\end{array}\right)$ & $\left(\frac{\mathrm{L}_{\mathrm{T}_{x}}}{\mathrm{~L}_{\mathrm{T}}}\right)^{3}$ & $\begin{array}{l}\text { Monthly increments of } \\
\text { weight. } \\
=\mathrm{K}\left\{\mathrm{L}_{\mathrm{T}}^{3}-\mathrm{L}_{\mathrm{x}}{ }^{3}\right\}\end{array}$ \\
\hline June 1st & $58 \cdot 3=\mathrm{L}_{\mathrm{r}_{1}}$ & $1 \cdot 0$ & - & \\
\hline July 1st & $78 \cdot 1=\mathrm{L}_{\mathrm{T}_{2}}$ & $2 \cdot 4$ & $2 \cdot 40$ & June $=\mathrm{K} \times 10^{4} \times 27.83$ \\
\hline Aug. 1st & $96 \cdot 8=\mathrm{L}_{\mathrm{T}_{3}}$ & $4 \cdot 6$ & 1.94 & July $=\mathrm{K} \times 10^{4} \times 43 \cdot 07$ \\
\hline Sept. 1st & $112 \cdot 0=\mathrm{L}_{\mathrm{T}_{4}}$ & $7 \cdot 1$ & 1.55 & Aug. $=\mathrm{K} \times 10^{4} \times 49 \cdot 78$ \\
\hline Oct. 1st & $102 \cdot 1=\mathrm{L}_{\mathrm{T}_{5}}$ & $8 \cdot 7$ & $1 \cdot 23$ & Sept. $=\mathrm{K} \times 10^{4} \times 32.70$ \\
\hline Nov. 1st & $123 \cdot 6=\mathrm{L}_{\mathrm{T}_{6}}$ & $9 \cdot 5$ & $1 \cdot 09$ & Oct. $=\mathrm{K} \times 10^{4} \times 15.60$ \\
\hline Dec. 1st & $126 \cdot 0=\mathrm{L}_{\mathrm{T}_{7}}$ & $10 \cdot 1$ & $1 \cdot 06$ & Nov. $=\mathrm{K} \times 10^{4} \times 11 \cdot 30$ \\
\hline
\end{tabular}

\section{Lynher Samples.}

The data for the Lynher samples are given in Tables IV and VI (pp. 318, 319), and shown graphically in Fig. 4. The median body length and corresponding total length at the beginning of each calendar month, and the successive monthly increments added, were as follows :-

$\begin{array}{cccc}\text { Median Body } & \begin{array}{c}\text { Median Total } \\ \text { Length. } \\ \text { Length. } \\ \text { 1927. }\end{array} & \begin{array}{c}\text { Median Total } \\ \text { Length. } \\ \text { mm. }\end{array} & \begin{array}{c}\mathrm{L}_{\mathrm{r}} \text { m. } \\ \text { Monthly increments. } \\ \text { mm. }\end{array} \\ \text { June 1st } & 59 & 68 \cdot 8 & \\ \text { July 1st } & 75 & 87 \cdot 5 & \text { June, } 18 \cdot 7 \\ \text { Aug. 1st } & 89 & 103 \cdot 8 & \text { July, } 16 \cdot 3 \\ \text { Sept. 1st } & 99 & 115 \cdot 5 & \text { Aug., } 11 \cdot 7 \\ \text { Oct. 1st } & 105 & 122 \cdot 5 & \text { Sept., } 7 \cdot 0 \\ \text { Nov. 1st } & 109 & 127 \cdot 1 & \text { Oct., } 4 \cdot 6 \\ \text { Dec. 1st } & 111 & 129 \cdot 5 & \text { Nov., } 2 \cdot 4\end{array}$

Thus, as for the fishes from the Tamar, the median total length increased most rapidly during June and July, and then less and less rapidly during the remaining months. It is to be noted, however, that the median total length on June 1st for the Lynher fishes was some $10 \mathrm{~mm}$. greater than the corresponding Tamar value. This initial difference, whatever its cause, would, to some extent at any rate, account for the fact that the monthly increments added are different; the Tamar fish, starting from the smaller June length of $58.3 \mathrm{~mm}$., adding the larger increment of $19 \cdot 8 \mathrm{~mm}$. during June, while the Lynher fish starting from the larger June length of $68.8 \mathrm{~mm}$., adding the smaller increment of $18.7 \mathrm{~mm}$. during June.

The superior median length of the Lynher fish at the commencement of the period of observation was undoubtedly due in a marked degree 
to the fact that the proportion of normal-tailed individuals was very much higher than in the Tamar during the same period. Thus, the first Lynher sample, taken on June 13th, 1927, included only 98 abnormaltailed specimens in a total of 613 , whereas a Tamar sample of 884 taken on June 23rd, 1927, included 602 abnormal-tailed specimens. We have already seen (p. 307) that on average the normal-tailed specimens of a sample were larger than the abnormal-tailed.

\section{Growth during First Season in Scaled Condition.}

In all estimations of age and growth of adult fishes from scale readings, it is essential that the investigator should possess precise knowledge of the significance of the first winter-ring (see Part I, p. 242). From the above results it may be concluded that by the end of November, 1927, practically all growth for the season had been made.

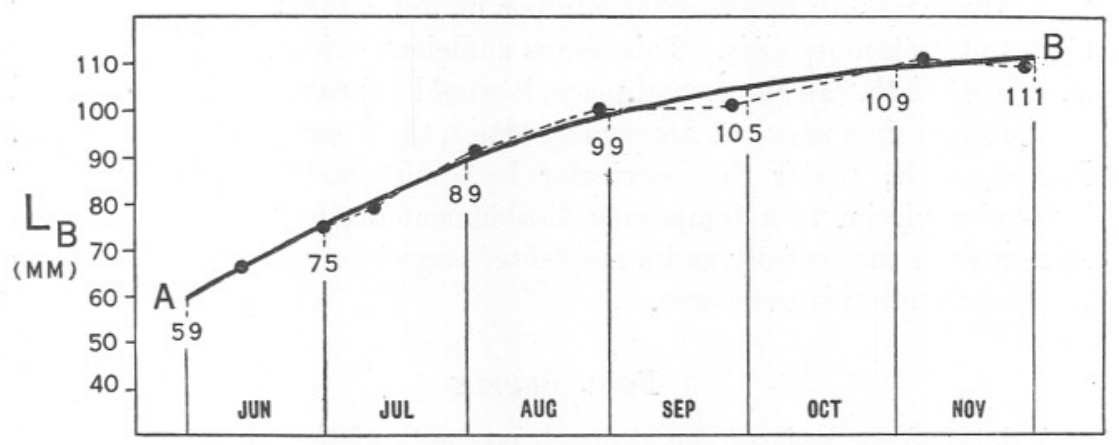

Fig. 4.-Median body length $\left(\mathrm{L}_{\mathrm{B}}\right)$ for samples of young herrings caught in Lynher, 1927. Details as in Fig. 2.

although some subsequent slight increase in length during the winter may yet be possible, especially on the part of the smaller specimens. Taking the Tavy sample of December 5th as an approximation to the final position, it is seen that there is a range in body length from about 80-140 mm., with a median value of approximately $110 \mathrm{~mm}$. Expressed as total length, the range is thus from about $90-160 \mathrm{~mm}$., with a median total length of approximately $130 \mathrm{~mm}$. Now it may be accepted that the great bulk of the small herrings captured on May 26th, 1927 (the first of the series of samples), had either acquired their scales or were in actual process of doing so in the calendar year 1927. Their subsequent growth to the median length of $130 \mathrm{~mm}$. by December thus represents the first season's growth in the scaled condition. When, therefore, these fish eventually grow to adults, they will show a first winter-ring at a length $l_{1}$ of approximately $130 \mathrm{~mm}$. on average, but with 
a range of variation of from $90-160 \mathrm{~mm}$. It is of interest and importance to note that the calculated values of $l_{1}$ for adult fishes visiting Plymouth during the winter season compare quite favourably with those for the young fishes taken from the Tamar and Lynher. Thus, in 1924-25, a total of 244 "4-zoned 4-ringed" fishes showed a range in $l_{1}$ from $85 \mathrm{~mm}$. to $175 \mathrm{~mm}$., with an average of $138.8 \mathrm{~mm}$. A total of 1122 fishes of the "5-zoned 5-ringed" class of the same season varied from 65 to $185 \mathrm{~mm}$. in their value of $l_{1}$, the average value being $128.6 \mathrm{~mm}$. That the scales of the young fish under discussion will actually show a winter-ring is proved by the fact that in the later samples the wellmarked clear "winter-edge" was beginning to appear, and was well established in the last samples.

The reason for the amount of variation in the length $l_{1}$ appears to be twofold. In the first place, the time of spawning undoubtedly plays its part. On May 26th, 1927, while many were fully scaled and growing well, there was an appreciable number of individuals still in the early stages of metamorphosis. This seems sufficient evidence of a difference in time of birth. In the second place, it would appear that fishes spawned at the same time may not necessarily attain the same ultimate length, $\mathrm{l}_{1}$. For example, under the particular local circumstances, a fish may become a victim to a temporary disablement of the tail and therefore not grow so successfully as its unaffected associate until (if such occurs) the tail affection is overcome.

\section{Food Supply}

A detailed analysis of the stomach contents of the fishes has not yet been completed, but from the observations so far made it is abundantly evident that the fully-scaled fishes were feeding throughout with great avidity almost entirely on mysids. The rivers abound with mysids, and the stomachs examined during the summer were always well filled.

\section{Acknowledgments.}

I am greatly indebted to Mr. J. H. Blake, of Saltash, both for constructing the successful small-meshed seine and for his skilful superintendence of the actual fishing operations. I wish also to thank Mr. W. Searle, of the Laboratory staff, for his willing and valuable services in the collection of the samples. 


\section{LITERATURE CITED.}

1. Davis, F. M. "An Account of the Fishing Gear of England and Wales." Revised Edition, 1927. Fish. Invest., Ser. II, Sea Fish., Vol. IX, No. 6, 1927.

2 ORton, J. H. "An Account of the Researches on Races of Herrings carried out by the Marine Biological Association at Plymouth, 1914-15." Journ. Mar. Biol. Assoc., Vol. XI, No. 1, 1916.

\section{TABLE I.}

Correlation Table. Body Length and Total Length

(Orton's Samples of Adult Fishes).

$$
1914-15 \text {. }
$$

Total Length. Central values for 11 length groups (cm.)

Arith.

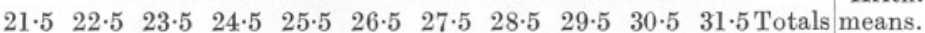

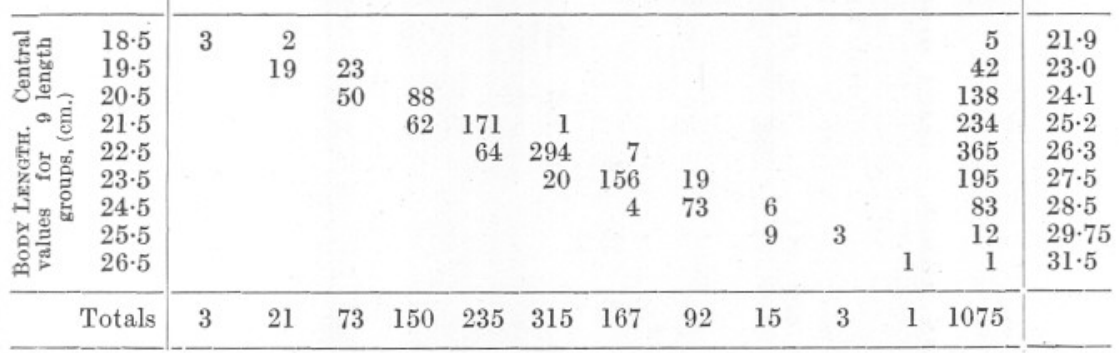




\section{TABLE II.}

Correlation Table. Body Length and Total Length. Young Herrings, Plymouth, 1927.

Total Length. Central Values for 26 length groups (5 mm.).

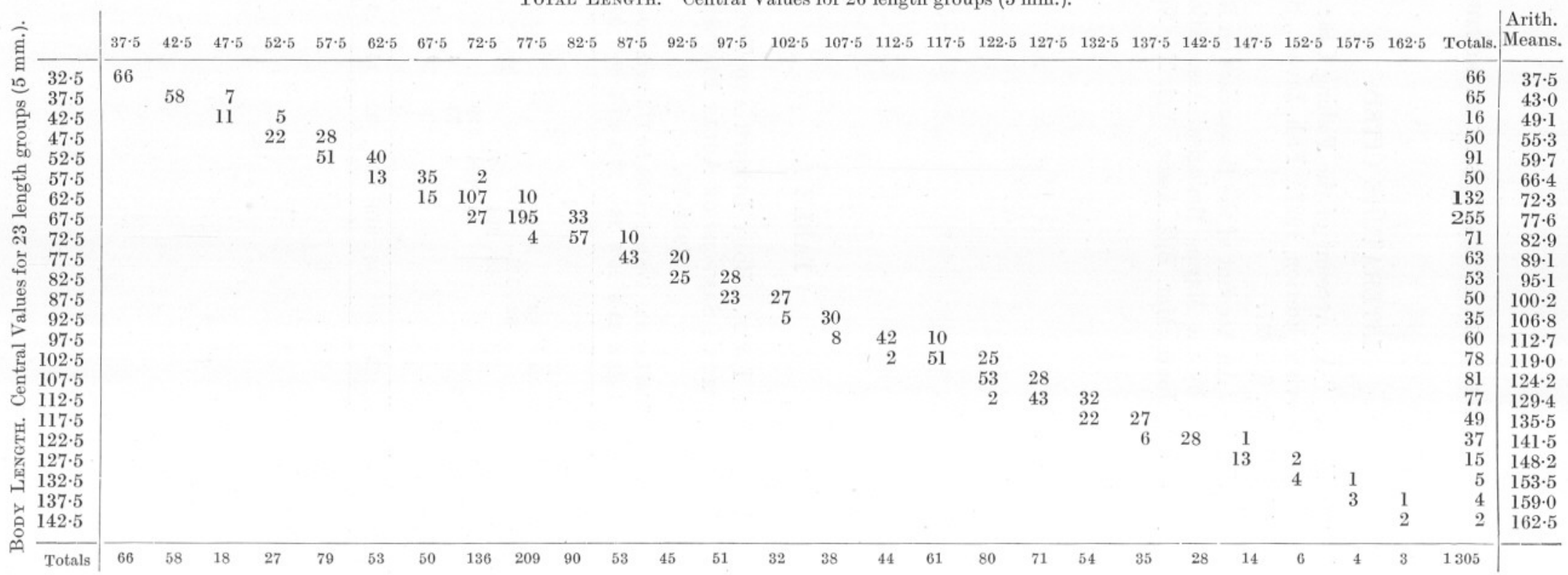


TABLE III.

Samples from Tamar and Tavy.

Body Length. $5 \mathrm{~mm}$. Groups.

Total

Condition

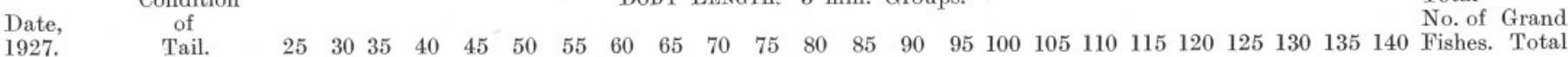

May 26th Normal

and

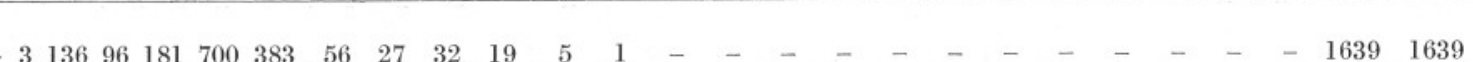

Abnormal

June 8th Normal Abnormal

June 23rd* Normal

Abnormal \}$_{-}^{-}$

$\begin{array}{lllllllll}13 & 26 & 20 & 85 & 146 & 102 & 77 & 39 & 1\end{array}$

$12 \quad 11 \quad 2$

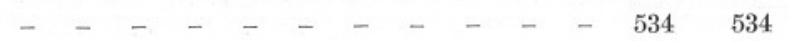

July 11th $\begin{aligned} & \text { Normal } \\ & \text { Abnormal }\end{aligned}$

Normal

Aug. 9th* Abnormal

Normal

Aug. 23rd Normal

Abnorma

Sept. 7th Normal

Abnormal

Sept. 20th Normal

$\begin{array}{ll}\text { Oct. 7th } & \begin{array}{l}\text { Normal } \\ \text { Abnorma }\end{array}\end{array}$

Normal

Oct. 20th Abnorma

Normal

Nov. 3rd $\begin{aligned} & \text { Normal } \\ & \text { Abnormal }\end{aligned}$

Nov. 21st Normal

Abnorma

Dec. 5th* Normal

* Tavy samples.

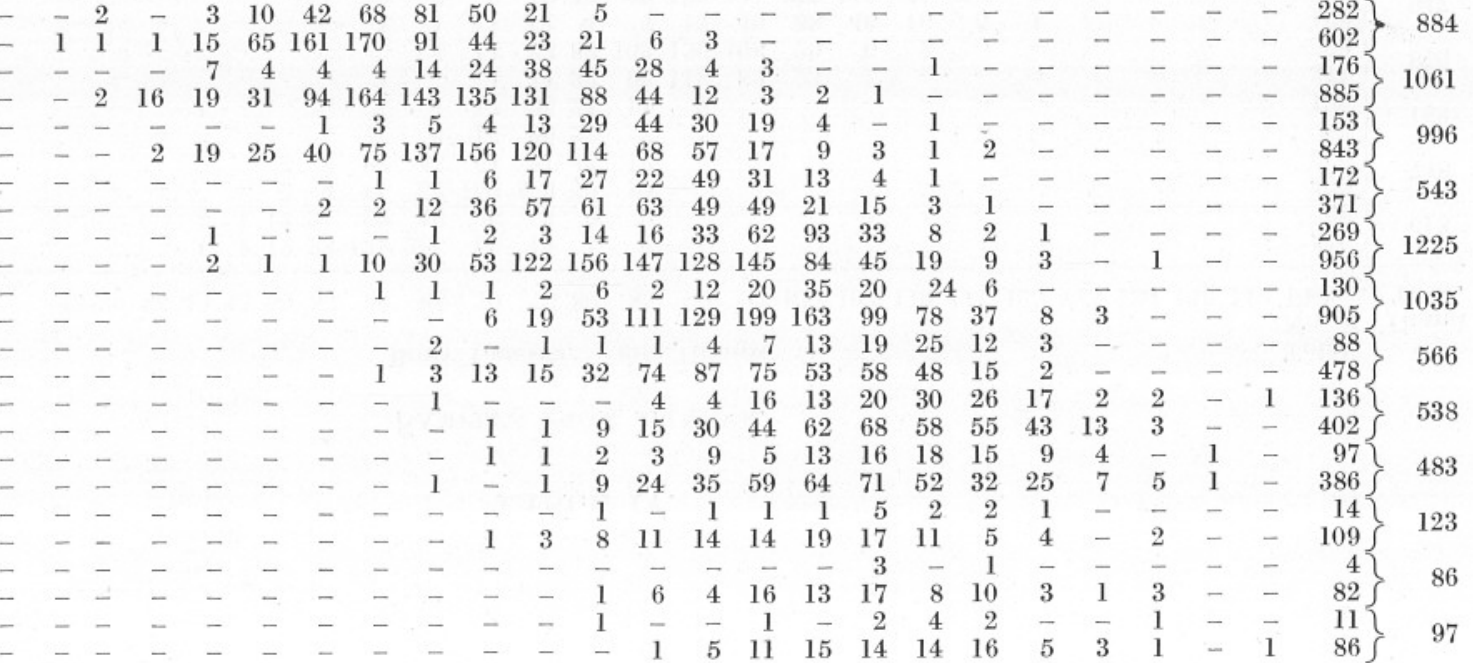


TABLE IV.

SAMPLes From Lynher.

\begin{tabular}{|c|c|c|c|c|c|c|c|c|c|c|c|c|c|c|c|c|c|c|c|c|c|c|c|c|c|c|c|}
\hline $\begin{array}{l}\text { Date, } \\
1927 .\end{array}$ & $\begin{array}{c}\text { Condition } \\
\text { of } \\
\text { Tail. }\end{array}$ & $25:$ & & 35 & 40 & 45 & 50 & 55 & 60 & 3ODY & LEN & NGTH. & 80 & $\mathrm{~mm}$. & 1. Gro & oups. & 100 & 105 & 110 & 115 & 120 & 125 & 130 & 135 & 140 & $\begin{array}{l}\text { Total } \\
\text { No. of } \\
\text { Fishes. }\end{array}$ & $\begin{array}{l}\text { Grand } \\
\text { Total. }\end{array}$ \\
\hline \multirow[t]{2}{*}{ June 13th } & Normal & - & - & - & 1 & 2 & 12 & 23 & 132 & 255 & 69 & 13 & 4 & 2 & 1 & 1 & - & - & - & - & - & - & - & - & - & $515\}$ & \multirow[b]{2}{*}{613} \\
\hline & Abnormal & - & - & - & - & 1 & 13 & 31 & 20 & 19 & 6 & 3 & 3 & 2 & - & - & - & - & - & - & - & - & - & - & - & $98\}$ & \\
\hline \multirow[t]{2}{*}{ July 1st } & Normal & - & - & - & - & - & 2 & 2 & 11 & 52 & 159 & 173 & 70 & 10 & - & - & - & - & - & - & - & - & - & - & - & $479\}$ & \multirow{2}{*}{748} \\
\hline & Abnormal & - & - & - & - & - & 3 & 6 & 23 & 43 & 64 & 71 & 43 & 12 & 4 & - & - & - & - & - & - & - & - & - & - & 269 & \\
\hline \multirow[t]{2}{*}{ July 12th } & Normal & - . & - & - & - & - & - & - & 1 & 6 & 16 & 29 : & 23 & 7 & 1 & - & - & - & - & - & - & - & - & - & - & $83\}$ & \multirow{2}{*}{183} \\
\hline & Abnormal & - & - & - & 1 & - & - & - & 1 & 4 & 17 & 35 & 24 & 11 & 7 & - & - & - & - & - & - & - & - & - & - & 100 & \\
\hline \multirow[t]{2}{*}{ Aug. 3rd } & Normal & - & - & - & - & - & - & - & 1 & - & 4 & $11:$ & 32 & 98 & 118 & 82 & 23 & 2 & - & - & - & - & - & - & - & $371\}$ & \multirow{2}{*}{879} \\
\hline & Abno & - & - & - & - & - & - & - & - & 4 & 14 & 23 & 83 & 103 & 136 & 108 & 29 & 6 & 2 & - & - & - & - & - & - & 508 & \\
\hline \multirow[t]{2}{*}{ Aug. 30th } & Normal & - & - & - & - & - & - & - & 1 & 1 & 1 & 1 & 4 & 7 & 17 & 40 & 58 & 46 & 16 & 5 & 1 & - & - & - & - & 198\{ & \multirow[b]{2}{*}{947} \\
\hline & Abnormal & - & - & - & - & - & - & - & 2 & 6 & 9 & 19 & 40 & 69 & 103 & 141 & 155 & 119 & 61 & 19 & 5 & 1 & - & - & - & $749\}$ & \\
\hline \multirow[t]{2}{*}{ Sept. 28th } & Norm: & - & - & - & - & - & - & - & - & - & - & - & - & - & 1 & - & - & 1 & - & - & - & 1 & - & - & - & $3\}$ & \multirow{2}{*}{131} \\
\hline & Abnormal & - & - & - & - & - & - & - & 3 & - & 2 & 1 & 11 & 18 & 9 & 16 & 20 & 18 & 14 & 10 & 1 & 2 & 2 & 1 & - & $128\}$ & \\
\hline \multirow[t]{2}{*}{ Nov. 7th } & Normal & - & - & - & - & - & - & - & - & - & - & 1 & - & - & - & 1 & 3 & 3 & 4 & 2 & 2 & 2 & - & - & - & 18\{ & \multirow{2}{*}{147} \\
\hline & Abnormal & - & - & - & - & - & - & - & - & - & 1 & 2 & - & 3 & 8 & 11 & 18 & 18 & 18 & 17 & 19 & 9 & 3 & 1 & 1 & $129\}$ & \\
\hline Nov. 29th & $\begin{array}{l}\text { Normal } \\
\text { and } \\
\text { Abnormal }\end{array}$ & - & - & - & - & - & - & - & - & - & 2 & - & 1 & 11 & 12 & 33 & 54 & 87 & 76 & 54 & 25 & 7 & 1 & - & - & 363 & 363 \\
\hline
\end{tabular}


TABLE V.

Samples from the Tamar and Tavy, 1927.

\begin{tabular}{|c|c|c|c|c|c|c|}
\hline Date. & $\begin{array}{c}\text { Total No. } \\
\text { of }\end{array}$ & \multicolumn{4}{|c|}{$\begin{array}{c}\text { Body-Length, Distribution. } \\
\text { Deciles, Quartiles, and Median (cm.). }\end{array}$} & \\
\hline 1927. & Fishes. & $d_{1}$. & $Q_{1}$ & $\mathrm{Q}_{2}$ & $Q_{3}$ & $d_{9}$ \\
\hline May 26th & 1639 & $3 \cdot 63$ & $4 \cdot 48$ & $4 \cdot 79$ & $5 \cdot 30$ & $5 \cdot 47$ \\
\hline June 8th & 534 & $4 \cdot 36$ & $4 \cdot 99$ & $5 \cdot 42$ & $6 \cdot 06$ & $6 \cdot 66$ \\
\hline June 23rd & 884 & $5 \cdot 43$ & $5 \cdot 80$ & $6 \cdot 30$ & $6 \cdot 86$ & $7 \cdot 45$ \\
\hline July 11th & 1061 & $5 \cdot 64$ & $6 \cdot 26$ & $7 \cdot 09$ & $7 \cdot 90$ & $8 \cdot 47$ \\
\hline July 25 th & 996 & $6 \cdot 09$ & $6 \cdot 80$ & $7 \cdot 63$ & $8 \cdot 54$ & $9 \cdot 27$ \\
\hline Aug. 9th & 543 & $7 \cdot 44$ & $8 \cdot 01$ & $8 \cdot 80$ & $9 \cdot 53$ & $10 \cdot 09$ \\
\hline Aug. 23rd & 1225 & $8 \cdot 09$ & $8 \cdot 83$ & $9 \cdot 67$ & $10 \cdot 48$ & $11 \cdot 00$ \\
\hline Sept. 7th & 1035 & $8 \cdot 56$ & $9 \cdot 20$ & $9 \cdot 90$ & $10 \cdot 57$ & $11 \cdot 26$ \\
\hline Sept. 20th & 566 & $8 \cdot 33$ & 8.99 & $9 \cdot 80$ & $10 \cdot 77$ & $11 \cdot 34$ \\
\hline Oct. 7 th & 538 & $9 \cdot 42$ & $10 \cdot 06$ & $10 \cdot 89$ & $11 \cdot 68$ & $12 \cdot 15$ \\
\hline Oct. 20th & 483 & $9 \cdot 07$ & $9 \cdot 77$ & $10 \cdot 59$ & $11 \cdot 34$ & $12 \cdot 08$ \\
\hline Nov. 3rd & 123 & $8 \cdot 47$ & $9 \cdot 23$ & $10 \cdot 20$ & $10 \cdot 93$ & $12 \cdot 04$ \\
\hline Nov. 21st & 86 & $9 \cdot 21$ & $9 \cdot 83$ & $10 \cdot 59$ & $11 \cdot 34$ & $11 \cdot 97$ \\
\hline Dec. 5th & 97 & $9 \cdot 62$ & $10 \cdot 18$ & $10 \cdot 97$ & $11 \cdot 65$ & $12 \cdot 22$ \\
\hline
\end{tabular}

TABLE VI.

SAMples From the LyNher, 1927.

Date.

1927.

June 13th

July 1st

July 12 th

Aug. 3rd

Aug. 30th

Sept. 28th

Nov. 7 th

Nov. 29th
Body-Length, Distribution.

\begin{tabular}{|c|c|c|c|c|c|}
\hline $\begin{array}{l}\text { Total No. } \\
\text { of }\end{array}$ & \multicolumn{5}{|c|}{$\begin{array}{c}\text { Body-Lengta, Distribution. } \\
\text { Deciles, Quartiles, and Median }(\mathrm{cm} \text {. }\end{array}$} \\
\hline Fishes. & $d_{1}$. & $Q_{1}$. & $\mathrm{Q}_{2}$ & $Q_{3}$ & $d_{9}$. \\
\hline 613 & $5 \cdot 80$ & $6 \cdot 23$ & $6 \cdot 63$ & $6 \cdot 91$ & $7 \cdot 29$ \\
\hline 748 & $6 \cdot 64$ & $7 \cdot 10$ & $7 \cdot 52$ & $7 \cdot 90$ & \\
\hline 183 & $7 \cdot 10$ & $7 \cdot 50$ & $7 \cdot 86$ & $8 \cdot 29$ & $8 \cdot 7$ \\
\hline 879 & $8 \cdot 12$ & $8 \cdot 57$ & $9 \cdot 13$ & $9 \cdot 59$ & \\
\hline 947 & $8 \cdot 57$ & $9 \cdot 32$ & $10 \cdot 03$ & $10 \cdot 61$ & $11 \cdot 0$ \\
\hline 131 & $8 \cdot 33$ & $8 \cdot 94$ & $10 \cdot 12$ & $10 \cdot 97$ & \\
\hline 147 & $9 \cdot 49$ & $10 \cdot 24$ & $11 \cdot 11$ & $12 \cdot 03$ & \\
\hline 363 & $9 \cdot 66$ & $10 \cdot 30$ & $10 \cdot 90$ & $11 \cdot 48$ & \\
\hline
\end{tabular}


